\title{
DINAMIKA ISLAM NUSANTARA \\ (Studi Perbandingan Islam Tradisional di Pulau Bangka dengan Konsep Islam Nusantara)
}

\author{
Kartika Sari \\ IAIN SAS Bangka Belitung \\ ti3k@yahoo.com
}

\begin{abstract}
ABSTRAK
This research compares the forms of traditional Islamic teaching on the Bangka island with the concept of 'Islam Nusantara' by Ahmad Baso. This research uses a qualitative method using social-historical. The object of this research is the traditional Islamic community in Bangka Island, including Pangkalpinang, Bangka Regency, Central Bangka Regency, West Bangka Regency, and South Bangka Regency. The results of this study showed that in terms of substance, the term 'Islam Nusantara' is an Islamic understanding and practice on the archipelago as a result of dialectics between Shari'a texts and local culture and reality. The spirit of 'Islam Nusantara' is an Islamic practice that is preceded by a dialectic between the sharia text and the reality and culture in which Muslims live. The perspective of ushul fiqh, the dialectical process between the sharia text and the reality and culture in which Muslims live is something normal that happens even when Islam is a universal conversation. ' Islam Nusantara' is a form of Islam as a universal religion, it has been embraced by millions of inhabitants of the archipelago and has collected thousands of legal products and other Islamic treasures. This is no different from the traditional Islamic concept on the island of Bangka. Traditional Islamic societies on the island of Bangka on certain seasons or days perform religious rituals such as nganggung. Nganggung is a form of conversion of non-Islamic beliefs to Islam. Not from a form that is converted from a dialectical form between Islamic texts and local culture. That is, Nganggung that still survive in the midst of Bangka society is not against Islam. If the Nganggung process is limited to conversion, of course there is no point in their Islam. A culture that has gained sharia legitimacy has become a ritual of worship. This process is something that is common in Kiai or ulama circles in the archipelago, including on the island of Bangka.
\end{abstract}

Kata Kunci: Islam Tradisional, Islam Nusantara, Pulau Bangka

\section{LATAR BELAKANG MASALAH}

Pada umumnya, Islam di Indonesia terbagi menjadi dua kelompok, yaitu Kelompok Islam tradisional dan kelompok Islam modern. Kelompok Islam tradisional merupakan kelompok atau golongan yang dalam pelaksanaan ibadahnya masih memelihara dan mempertahankan tradisi Islam yang diterima secara turun temurun. Sedangkan kelompok Islam modern merupakan kelompok atau golongan yang lebih mementingkan pemurnian dan pembaharuan aspek-aspek ajaran Islam sesuai dengan tuntutan kehidupan masyarakat modern. Dua orientasi keagamaan ini sangat berbeda dan seringkali mengalami benturan ideologis sehingga tidak jarang ditemui konflik terbuka diantara penganut dua kelompok tersebut.

Kelompok Islam tradisionalis merupakan kelompok yang lebih banyak menghiraukan masalah-masalah ibadah belaka dan cenderung menyamakan Islam dengan fiqh, di samping kecenderungan yang kuat pada sufisme. Sementara Islam modern lebih banyak memperhatikan sifat Islam pada umumnya, yaitu Islam sebagai agama yang universal. Pikiran dan aksi mereka mengikuti syariat yang telah digariskan dal Al-Quran dan Hadits. Penganut Islam tradisional sering kali dicap sebagai kelompok masyarakat yang kolot, pasif, dan ketinggalan jaman sehingga tidak jarang mereka dianggap sebagai kelompok yang antipati terhadap perkembangan 
dan kemajuan masyarakat. Penganut Islam modern lebih terbuka terhadap perubahan sehingga terkesan tidak kaku dalam melaksanakan ajaran-ajaran Islam. ${ }^{1}$

Namun, baru-baru ini muncul istilah baru yang merujuk kepada kelompok atau penganut ajaran Islam baru di Indonesia. Mereka menamakan istilah tersebut dengan istilah 'Islam Nusantara'. Secara sekilas, Islam nusantara hampir sama dengan Islam tradisional dalam beberapa aspek. Lalu kenapa harus diberi nama Islam nusantara jika dalam pandangan dan tata cara pelaksanaan ibadah sama dengan Islam tradisional? Ada beberapa buku yang membahas mengenai konsep Islam Nusantara. Namun dalam hal ini, penulis memilih satu buku yang menjadi landasan dalam penelitian ini, yaitu buku karangan Ahmad Baso yang berjudul "Islam Nusantara: Ijtihad Jenius \& Ijma' Ulama Nusantara, Jilid I" yang diterbitkan oleh Pustaka Afid Jakarta tahun 2015

Buku ini membicarakan tentang Islam Nusantara dari sisi konstruksi atau racikan ulamaulama Nusantara (Indonesia), dari dalam pesantren, sebagaimana ditulis, didakwahkan oleh para ulama Nusantara, dan diamalkan oleh mayoritas bangsa Indonesia. Awal kemunculan buku ini sempat mengundang kontroversi. Istilah Islam Nusantara banyak dibicarakan oleh sebagian masyarakat Indonesia sebagai upaya memudarkan ajaran Islam itu sendiri. Mereka berpendapat bahwa tidak ada istilah Islam Nusantara karena Islam adalah Islam, tidak mengenal Islam yang bersifat ke-daerahan,kesukuan, atau mewakili suatu Negara. Islam turun ke dunia untuk seluruh umat manusia, Islam itu rahmatan lil alamin. Islam itu dibangun di atas landasan yang satu, yaitu Alquran dan Sunnah.

Buku ini menjelaskan bahwa maksud dari istilah Islam Nusantara adalah Islam yang selain dibangun di atas landasan Alquran dan Sunnah,Islam memiliki acuan maqashid syaria'ah (tujian syariat). Tujuan syariat ini dapat digali dari nash-nash syariah melalui sekian istiqro' (penelitian induktif). Ulama-ulama terdahulu menjelaskan bahwa di balik aturan-aturan syariat ada tujuan yang hendak dicapai, yaitu terwujudnya kemaslahatan manusia di dunia dan akhirat. Kemaslahatan semakna dengan kebaikan dan kemanfataan. Tujuan Negara dalam Islam sejatinya sejalan dengan tujuan syariat, yaitu terwujudnya keadilan dan kemakmuran yang berKetuhanan yang Maha Esa. Oleh karena itu, istilah Islam Nusantara sejati menggambarkan bahwa tujuan Islam sejalan dengan terbentuknya Nusantara (Indonesia).

Oleh karenanya, prinsip-prinsip menjalankan ajaran Islam sepenuhnya harus selalu berpegang teguh dengan Alquran dan Sunnah. Selain itu, prinsip-prinsip tersebut juga dapat disesuaikan dengan dalil-dalil sekunder (selain Alquran dan Sunnah) sepanjang prinsip-prinsip tersebut tidak memiliki acuan nash secara langsung. Dalil-dalil sekunder yang dimaksud seperti Ijma, al-Qiyas, Istihsan, Saddu-dz-dzariah, 'urf, dan lain-lainnya. Hal tersebut juga menjelaskan bahwa hukum itu tidak selalu tekstual tetapi juga kontekstual sepanjang tujuannya adalah kemaslahatan. Istilah Islam Nusantara hanya sebagai lambang bahwa faham dan praktik keislaman di bumi Nusantara adalah sebagai hasil dialektika antara teks syariat dengan realita dan budaya setempat.

Makna istilah Islam Nusantara adalah pemahaman, pengamalan, dan penerapan Islam dalam segmen fiqih mu'amalah sebagai hasil dialektika antara nash, syari'at, dan 'urf, budaya, dan realita di bumi Nusantara. Dalam istilah "Islam Nusantara" tidak ada sentimen benci terhadap bangsa dan budaya negara manapun, apalagi negara Arab, khususnya Saudi sebagai tempat kelahiran Islam dan bahasanya menjadi bahasa Al-Qur'an. ${ }^{2}$

Islam Nusantara merupakan istilah yang merujuk pada Islam yang Indonesia. Istilah Nusantara merupakan nama lain dari Indonesia. Disebut nusantara sebab wilayah ini tendiri dari banyak pulau (nusa $=$ pulau, tara $=$ antara). Sehingga singkat kata, Islam Nusantara adalah Islam yang tetap memelihara adat kebiasaan turun-temurun masyarakat di Indonesia.

\footnotetext{
${ }^{1}$ Zulkifli. Kontuinitas Islam Tradisional di Bangka. Bangka: Shiddiq Press.

${ }^{2}$ KH Afifuddin Muhajir. http://www.nu.or.id/post/read/60458/maksud-istilah-islam-nusantara. Diakses pada tanggal 5 Maret 2016.
}

SCIENTIA, VOL.3, NO. 2, DESEMBER 2018 
Dalam penjelasanya, KH. Afifudin Muhajir ${ }^{3}$ mengatakan bahwa Al-Quran sebagai sumber utama Agama Islam memuat tiga ajaran. Pertama, ajaran akidah, yaitu sejumlah ajaran yang berkaitan dengan apa yang wajib diyakini oleh mukallaf menyangkut eksistensi Allah, malaikat, para utusan, kitab-kitab Allah, dan hari pembalasan. Kedua, ajaran akhlak/tasawuf, yaitu ajaran yang berintikan takhalli dan tahalli, yakni membersihkan jiwa dan hati dari sifat-sifat tercela dan menghiasinya dengan sifat terpuji. Ketiga, ajaran syariat, yaitu aturan-aturan praktis (alahkam al-'amaliyah) yang mengatur perilaku dan tingkah laku mukallaf, mulai dari peribadatan, pernikahan, transaksi, dan seterusnya.

Yang pertama dan kedua sifatnya universal dan statis, tidak mengalami perubahan di manapun dan kapanpun. Tentang keimanan kepada Allah dan hari akhir tidak berbeda antara orang dahulu dan sekarang, antara orang-orang benua Amerika dengan benua Asia. Demikian juga, bahwa keikhlasan dan kejujuran adalah prinsip yang harus dipertahankan, tidak berbeda antara orang Indonesia dengan orang Nigeria. Penipuan selalu buruk, di manapun dan kapanpun. Dalam segmen keyakinan dan tuntunan moral ini, Islam tidak bisa di-embelembeli dengan nama tempat, nama waktu, maupun nama tokoh.

Sementara yang ketiga, yaitu ajaran syari'at, masih harus dipilah antara yang tsawabith/qath'iyyat danijtihadiyyat. Hukum-hukum qath'iyyat seperti kewajiban shalat lima kali sehari semalam, kewajiban puasa, keharaman berzina, tata cara ritual haji, belum dan tidak akan mengalami perubahan (statis) walaupun waktu dan tempatnya berubah. Shalatnya orang Eropa tidak berbeda dengan salatnya orang Afrika. Puasa, dari dahulu hingga Kiamat dan di negeri manapun, dimulai semenjak Subuh dan berakhir saat kumandang azan Maghrib. Penjelasan Al-Quran dan As-Sunah dalam hukum qath'iyyat ini cukup rinci, detil, dan sempurna demi menutup peluang kreasi akal. Akal pada umumnya tidak menjangkau alasan mengapa, misalnya, berlari bolak-balik tujuh kali antara Shafa dan Marwa saat haji. Oleh karena itu akal dituntut tunduk dan pasrah dalam hukum-hukum qath'iyyat tersebut.

Sementara itu, hukum-hukum ijtihadiyyat bersifat dinamis, berpotensi untuk berubah seiring dengan kemaslahatan yang mengisi ruang, waktu, dan kondisi tertentu. Hukum kasus tertentu dahulu boleh jadi haram, tapi sekarang atau kelak bisa jadi boleh. Al-Quran dan AsSunah menjelaskan hukum-hukum jenis ini secara umum, dengan mengemukakan prinsipprinsipnya, meski sesekali merinci. Hukum ini memerlukan kreasi ijtihad supaya sejalan dengan tuntutan kemaslahatan lingkungan sosial.

Para tabi'in berpendapat bahwa boleh menetapkan harga (tas'ir), padahal Nabi Muhammad Shallallahu Alaihi wa Sallam melarangnya. Tentu saja mereka tidak menyalahi AsSunah. Perbedaan putusan itu karena kondisi pasar yang berubah, yaitu bahwa pada masa Nabi SAW harga melambung naik karena kelangkaan barang dan meningkatnya permintaan, sedangkan pada masa tabi' in disebabkan keserakahan pedagang. Di sini, para tabi'in membedakan antara-apa yang disebut ekonomi modern dengan-pasar persaingan sempurna dari pasar monopoli atau oligopoli misalnya.

Jadi, menurut hukum ijtihadiyyat tersebut, pemakaian nama seperti Islam Nusantara bolehboleh saja dan tidak menyalahi As-Sunah karena istilah tersebut hanya merujuk pada ruang dan waktu dimana Islam itu berada, namun secara akidah dan akhlak tidak berubah. Istilah ini hanya dipakai untuk menggambarkan pluralisme atau bentuk toleransi sesama pemeluk Islam di Indonesia yang berbeda pulau, suku, ras, dan budaya.

Konsepsi "Islam Nusantara" mengacu pada fakta sejarah betapa dakwah Islam di nusantara tidak dilakukan dengan pemberangusan terhadap budaya setempat, melainkan justru dengan merangkul dan menyelaraskannya dengan Islam. Melalui Islam Nusantara, kelompok ini bertekad mempertahankan Islam Nusantara yang berciri toleran, moderat dan damai. Namun dari pandangan yang kontra, "Islam Nusantara" dianggap sebagai bermuatan primordial, anti-

\footnotetext{
${ }^{3}$ KH Afifuddin Muhajir. http://www.nu.or.id/post/read/60458/maksud-istilah-islam-nusantara. Diakses pada tanggal 5 Maret 2016
} 
Arab, bahkan dituduh sebagai strategi baru dari JIL, Barat, Zionis, dan semacamnya.

Maksud dari istilah Islam Nusantara adalah Islam yang selain dibangun di atas landasan Alquran dan Sunnah,Islam memiliki acuan maqashid syaria'ah (tujian syariat). Tujuan syariat ini dapat digali dari nash-nash syariah melalui sekian istiqro' (penelitian induktif). Ulamaulama terdahulu menjelaskan bahwa di balik aturan-aturan syariat ada tujuan yang hendak dicapai, yaitu terwujudnya kemaslahatan manusia di dunia dan akhirat. Kemaslahatan semakna dengan kebaikan dan kemanfataan. Tujuan Negara dalam Islam sejatinya sejalan dengan tujuan syariat, yaitu terwujudnya keadilan dan kemakmuran yang ber-Ketuhanan yang Maha Esa. Oleh karena itu, istilah Islam Nusantara sejati menggambarkan bahwa tujuan Islam sejalan dengan terbentuknya Nusantara (Indonesia). ${ }^{4}$

Sedangkan dari sisi substansi, terma 'Islam Nusantara' itu paham dan praktik keislaman di bumi Nusantara sebagai hasil dialektika antara teks syariat dengan realita dan budaya setempat. Spirit 'Islam Nusantara' adalah praktik berislam yang didahului dialektika antara nash syariah dengan realitas dan budaya tempat umat Islam tinggal. Perspektif ushul fiqh, proses dialektika antara nash syariah dengan realitas dan budaya tempat umat Islam tinggal itu sesuatu yang lumrah terjadi bahkan pasti terjadi mengingat Islam itu ajaran yang universal. Dan 'Islam Nusantara' adalah wujud Islam sebagai agama universal mengingat ia telah dipeluk oleh ratusan juta penduduk Nusantara dan telah melahirkan ratusan ribu produk hukum dan khazanah keislaman lainnya.

Lalu bagaimanakah dengan Islam di pulau Bangka? Apakah budaya dan adat Islam masyarakat pulau Bangka dapat dikategorikan sebagai Islam Nusantara? Penelitian ini akan berusaha mengungkap karakter Islam tradisional di pulau Bangka. Mendeskripsikan kebudayaan masyarakat Islam di pulau Bangka dan kemudian membandingkan Islam tradisional di puelau Bangka dengan konsep Islam Nusantara menurut pandangan Ahmad Baso.

Seperti yang telah didengungkan oleh beberapa tokoh agama di Indonesia, Islam Nusantara merupakan bentuk aplikasi dari ajaran Islam yang bersifat universal. Islam yang terbuka dengan segala perubahan dan tanpa meninggalkan sifat kedaerahan. Islam nusantara memberikan askes kepada umat Islam untuk menjalankan ajaran Islam tidak hanya bersumber dari Al-quran dan Hadits, namun juga menjadikan budaya dan adat masing-masing daerah sebagai media penyebaran ajaran Islam. Melihat keanekaragaman budaya di Indonesia, Islam Nusantara mencoba memberikan solusi terbaik dalam memerangi perpecahan dikalangan umat Islam khususnya menyangkut perbedaan tata cara dan pelaksanaan ibadah kemasyarakatan.

Islam Nusantara melihat bahwa hukum Islam yang sifatnya dinamis (ijtihadiyat) memberikan celah bagi umat Islam di Indonesia yang berbeda-beda pulau dan budaya untuk menjalankan ibadahnya dengan membawa budaya setempat. Seperti di pulau Bangka misalnya. Pulau yang dihuni oleh sebagian besar masyarakat Melayu ini memiliki budaya yang berbeda dengan pulau-pulau lain di Indonesia. Banyak budaya masyarakat yang berkaitan dengan Islam yang berbeda dengan daerah lain seperti Nganggung, pembuatan nasi Kebuli, perayaan Maulid Nabi yang sangat meriah melebihi hari raya Ied, dan lain sebagainya. Budaya-budaya inilah yang menurut pandangan Islam Nusantara harus terus dipelihara demi tetap mempertahankan kekhasan Nusantara tanpa harus merusak nilai-nilai Islam yang terkandung di dalamnya.

Banyak buku dan penelitian tentang Islam di pulau Bangka, namun pada umumnya hanya sebatas penyebutan bahwa, Islam di Pulau Bangka terbagi menjadi dua kelompok, yaitu kelompok Islam tradisional dan Islam Modern. Di kampung-kampung, banyak dijumpai pelaksanaan ibadah maupun perayaan-perayaan hari Islam yang dibumbui dengan tradisi-tradisi masyarakat. Masyarakat dan praktek ibadah Islam yang disebut sebagai kelompok Islam

${ }^{4}$ Ahmad Baso. Islam Nusantara: Ijtihad Jenius \& Ijma' Ulama Nusantara, Jilid I. Jakarta: Pustaka Afid Jakarta, 2015, hal. viii 
tradisionalis. Lalu bisakah kelompok Islam tradisionalis tersebut dikatergorikan sebagai Islam Nusantara sesuai dengan arti Islam Nusantara itu sendiri? apakah pengamalan ajaran Islam di pulau Bangka tersebut dapat memenuhi kriteria sebagai Islam Nusantara? Adakah perbedaan dan persamaan Islam tradisional dan Islam Nusantara di pulau Bangka? Penelitian ini akan berusaha memaparkan karakter adat dan budaya Islam masyarakat Bangka dan mengaikatkan dengan istilah Islam Nusantara. Mengungkap sejarah perkembangan dan perubahan-perubahan budaya Islam serta akan berusaha menggambarkan persamaan dan perbedaan Islam tradisionalis dan Islam Nusantara di pulau Bangka.

Penelitian tentang Islam di pulau Bangka masih sangat terbatas. Ada beberapa penelitian yang membahas Islam di pulau Bangka, namun penelitian tersebut umumnya hanya membahas sejarah dan perkembangan Islam serta tradisi-tradisi Islam di pulau Bangka, belum merambah tentang Islam Nusantara di Bangka sehingga menurut hemat penulis, penelitian ini akan sangat menarik untuk dikaji dan dapat menambah wawasan pembaca mengenai Islam di pulau Bangka dengan up to date dan lebih komprehensif.

\section{LANDASAN TEORI.}

\section{Islam Tradisional}

Islam tradisional merupakan salah satu corak paham keislaman yang paling populer dan banyak dianut oleh masyarakat Indonesia. Paham keislaman ini sering dikonfrontir dengan Islam modernis yang menuduh Islam tradisional sebagai penghambat kemajuan dan membawa kemunduran umat Islam. Berbagai pemikiran yang dilakukan kaum modernis untuk membawa umat Islam kepada kemajuan adalah dengan terlebih dahulu meninggalkan sikap tradisionalnya.

Pengertian Islam Tradisional Berasal dari bahasa Inggris, "tradition" artinya tradisi. Dalam kamus bahasa Indonesia, kata tradisi diartikan segala sesuatu, seperti adat, kepercayaan, kebiasaan, ajaran dan sebagainya yang turun temurun dari nenek moyang. ${ }^{5}$ Sehingga Islam tradisional dapat dikatakan sebagai corak ajaran Islam yang tetap memberikan ruang bagi adatistiadat atau kepercayaan dalam menjalakan ibadah keagamaan. Umumnya, pelaksanaan adatistiadat yang melekat dalam masyarakat dicampur-adukan dengan ajaran Islam, seperti upacara selamatan yang sebenarnya merupakan adat-istiadat yang kemudian dibumbui dengan ajaranajaran Islam seperti pembacaan sholawat ataupun ayat suci Al-quran.

Dalam beberapa dekade, studi tentang Islam tradisional sudah sangat banyak dilakukan. Dari beberapa referensi buku yang penulis baca, penelitian-penelitian tersebut pada intinya menyimpulkan bahwa pemahaman dan praktik keagamaan yang dianut Islam tradisional memiliki dasar-dasar doktrin yang kokoh. Ajaran Islam tradisional tidak bersifat statis dan tertutup dengan perubahan. Dalam batas-batas tertentu, Islam tradisional tetap diinterpretasi kembali sesuai dengan perubahan sosiokultural, apalagi bila berhadapan dengan persoalanpersoalan yang belum dibahas secara detail dan belum ada keputusan hokum dalam Al-quran, Hadits, dan pendapat para ulama.

Zulkifli $^{6}$ menjelaskan bahwa meskipun beberapa studi tentang Islam tradisional sudah dilakukan tetapi kebanyakan masih berpendirian bahwa Islam tradisional itu merupakan entitas yang monopolitik, tanpa menunjukan variasi yang terdapat di dalamnya. Hal ini menunjukan kekurangan nuansa analisis sehingga Islam tradisional hanya menunjuk kepada satu pemahaman dan praktik keagamaan yang dikontradiksikan dengan Islam modern. Padahal, perbedaan kondisi sosiokultural suatu masyarakat akan melahirkan corak Islam tradisional tersendiri. Oleh karena itu, studi tentang Islam tradisional di Pulau Bangka ini diharapkan mampu merefleksikan Islam tradisional secara bulat dan utuh dengan variasi-variasi yang terdapat di dalamnya.

\footnotetext{
${ }^{5}$ W.J.S. Purwadarminta. Kamus Umum Bahasa Indonesia. Jakarta: Balai Pustaka, 1991, hal. 1088

${ }^{6}$ Zulkifli. Kontinuitas Islam Tradisional di Pulau Bangka. Bangka: Shiddiq Press, 2012, hal. 5.
} 


\section{Islam Nusantara}

Islam Nusantara adalah Islam yang ramah, terbuka, dan inklusif. Dikatakan pula sebagai mampu memberi solusi terhadap masalah-masalah besar bangsa dan negara. Islam yang dinamis dan bersahabat dengan lingkungan kultur, sub-kultur, dan agama yang multi. Islam bukan hanya cocok diterima bumi Nusantara, tetapi juga mewarnai bersifat akomodatif terhadap budaya Nusantara, yakni rahmatan lil 'alamin. Abdul Mun'im DZ (2010) menandaskan, Islam Nusantara adalah paham keislaman yang berdialog dan menyatu dengan kebudayaan Nusantara, melalui proses seleksi, akulturasi dan adaptasi.

Sebenarnya istilah 'Islam Nusantara' pada dasarnya tidaklah baru. Menurut Azyumardi Azra ${ }^{7}$ istilah ini mengacu pada Islam di gugusan kepulauan atau benua maritim (nusantara) yang mencakup tidak hanya kawasan Indonesia, tetapi juga wilayah Muslim Malaysia, Thailand Selatan (Patani), Singapura, Filipina Selatan (Moro), dan juga Champa (Kampuchea). Bagi Azra, "Islam Nusantara adalah Islam distingtif sebagai hasil interaksi, kontekstualisasi, indigenisasi dan vernakularisasi Islam universal dengan realitas sosial, budaya dan agama di Indonesia. Ortodoksi Islam Nusantara (kalam Asy'ari, fikih mazhab Syafi'i, dan tasawuf Ghazali) menumbuhkan karakter wasathiyah yang moderat dan toleran. Islam Nusantara yang kaya dengan warisan Islam (Islamic legacy) menjadi harapan renaisansperadaban Islam global"

Islam nusantara bukan Islam lokal. Ahmad Baso ${ }^{8}$ menegaskan Islam nusantara sebagai cara bermadzhab secara qauli dan manhaji dalam ber-istimbath tentang Islam dari dalil-dalilnya yang disesuaikan dengan teritorial, kondisi alam, dan cara pengamalannya penduduk kita. Islam nusantara itu sejajar dengan kajian Islam India, Islam Turki, Islam Yaman dan sebagainya. Jika Islam Nusantara merupakan proses berkelanjutan, maka bentuk paradigma dan etika Islam yang selalu senada dengan gerak sejarah. Islam Nusantara ialah faham dan praktik keislaman di bumi Nusantara sebagai hasil dialektika antara teks syariat dengan realita dan budaya setempat.

\section{ANALISIS DAN PEMBAHASAN}

\section{A. Islam Tradisional di Pulau Bangka}

1. Sistem Keyakinan

Islam Tradisional yang berkembang di Pulau Bangka hampir sama dengan Islam tradisional yang berkembang di daerah lain seperti di Jawa, Palembang, Aceh, dan lainnya. Hal ini disebabkan oleh proses islamisasi yang terjadi memiliki kesamaan karakteristik Antara daerah yang satu dengan daerah yang lainnya. Penyebaran Islam yang terjadi di Indonesia pada umumnya melalui perdagangan dan perkawinan. Penganut Islam tradisional di Pulau Bangka menggunakan istilah ahl-sunnah wa al-jama'ah untuk menyebut praktik keislaman yang dianut sama dengan apa yang dianut di daerah lainnya. Menurut zulkifli ${ }^{9}$, Islam di Bangka hampir sama dengan Islam tradisional yang diformulasikan oleh Dhofier, yakni Islam yang masih terikat kuat dengan pikiran-pikiran para ulama ahli fiqh (hokum Islam), hadits, tafsir, tauhid (teologi Islam) dan tasawuf yang hidup Antara abad ke-7 sampai abad ke-13.

Dalam konsep keyakinan Islam tradisional di Bangka, tauhid atau ushuludin merupakan aspek paling utama dalam menjalankan ajaran Islam. Pengetahuan mengenai tauhid ini sangat penting dimiliki oleh masyarakat Bangka terutama para kaum ulama atau Guru. Pemahaman ilmu tauhid yang mendalam dan luas memiliki arti bahwa orang tersebut memiliki ilmu agama

\footnotetext{
7 Azyumardi Azra, Jaringan Ulama Timur Tengah dan Kepulauan Nusantara Abad XVII dan XVIII, Akar Pembaruan Islam Indonesia, Edisi Revisi, Cet. 1 (Jakarta: Kencana, 2015), hlm. 118-119

${ }^{8}$ Ahmad Baso. Islam Nusantara: Ijtihad Jenius \& Ijma' Ulama Nusantara, Jilid I. Jakarta: Pustaka Afid Jakarta, 2015, hal. ix

${ }^{9}$ Zulkifli. Kontuinitas Islam Tradisional di Bangka. Bangka: Shiddiq Pres, 2007, hal. 31.
} 
yang tinggi. Sehingga orang tersebut memiliki syarat untuk menjadi seorang ulama atau Guru atau tokoh agama di lingkungan masyarakat. Inti pemahaman yang mendalam tentang ilmu tauhid dikalangan ulama dan tokoh agama bertujuan untuk mengesakan Allah Yang Maha Esa dan juga menjelaskan keterkaitan dan ketergantungan manusia dengan-Nya. Menurut mereka, pemahaman akan keyakinan tersebut menghindarkan diri manusia dari berbagai bentuk syirik dan melahirkan sikap pandangan yang tepat berkenaan dengan hubungan manusia dengan Tuhan.

Keyakinan akan Tuhan yang mendalam secara tidak langsung akan mempengaruhi keyakinan mereka terhadap makhluk-makhluk ciptaan Tuhan seperti malaikat, jin dan iblis. Keyakinan ini tercermin dari kemampuan mereka mengenal dan memahami nama beserta tugas-tugas yang diemban oleh malaikat-malaikat Allah serta paham bahwa iblis adalah musuh yang tidak kasat mata yang harus selalu diwaspadai bisikan-bisikannya. Mereka yakin bahwa ada makhluk ghaib yang diciptakan oleh Allah yang tidak terlihat oleh mata yang diturunkan ke dunia ini dengan maksud dan tujuan tertentu. Selain itu, orang Bangka juga percaya akan adanya hantu, meskipun tidak jelas keberadaan dan konsepnya. Menurut Zulkifli ${ }^{10}$, orang Bangka percaya bahwa pocong itu ada, mereka menyebutnya sebagai menyadin.

Masyarakata Islam tradisional di Bangka juga sepenuhnya percaya akan Nabi dan kitabkitab Allah. Meskipun nabi yang diturunkan oleh Allah ratusan jumlahnya, masyrakat Bangka tahu jika yang wajib diketahui hanya 25 Nabi, termasuk Nabi Muhammad sebagi Nabi terakhir yang turun ke dunia ini. Masyarakat Bangka tahu bahwa ada lima Nabi yang secara khusus di sebut sebagai ulu al-'azmi ( Nabi Nuh, Nabi Ibrahim, Nabi Musa, Nabi Isa, dan Nabi Muhammad SAW). Selain itu masyarakat Islam tardisional Bangka sangat meyakini bahwa akan datang waktu di mana seluruh makhluk yang ada di planet Bumi ini musnah karena kiamat. Mereka juga meyakini akan kehidupan setelah kematian, hari kebangkitan dan pembalasan.

2. Ibadah

Sistem keyakinan masyarkat yang dianut kemudian secara nyata dilaksanakan dengan tindakan yaitu dengan beribadah. Secara umum, masyarakat Islam tradisional di Bangka menganut mazhab fiqh Syafi'iyah, namun tidak menyalahkan bagi siapa saja yang mengikuti mahzab-mahzab lain seperti Hanafiyah, Malikiyah, dan Hanbaliyah.

Menurut Zulkifli ${ }^{11}$, dasar utama ajaran fiqh yang berkembang di Bangka beranjak dari konsep rukun islam yang lima sebagai dasar ibadah yang wajib dilaksanakan. Rukun Islam tersebut dijabarkan sebagai kewajiban untuk mengucapkan dua kalimat syahadat, mendirikan sholat, melaksanakan puasa Ramadhan, membayar zakat, dan menunaikan ibadah haji ke Mekah. Jika rukun Islam tersebut dilaksanakan dengan baik, maka seseorang dianggap telah menunaikan kewajiban yang diperintahkan Allah, sehingga diyakini akan mendapat pahala dari Nya dan akan masuk surge yang penuh dengan kenikmatan, tetapi jika tidak taat dan tunduk kepada Allah, maka balasanya adalah siksaan yang kelak akan didapat di neraka.

3. Adat

Adat atau budaya yang melekat dalam sistem masyarakat Islam tradisional di Bangka umumnya hampir sama dengan budaya daerah lain. Yasinnan atau tahlilan hampir pasti ada dalam kehidupan seluruh warga muslim di Bangka. Upacara-upacara keagamaan seperti memperingati hari kematian (tiga, tujuh, seribu hari) rutin dilaksanakan oleh umat Islam tradisional di Bangka. Namun, ada beberapa upacara atau kegiatan-kegiatan keagamaan yang berbeda seperti upacara nganggung dan peringatan hari-hari besar Islam.

\section{a. Nganggung}

\footnotetext{
${ }^{10}$ Ibid, hal. 38.

11 Ibid, hal. 41.
} 
Nganggung, yaitu sebuah kegiatan membawa dulang berisi makanan ke mesjid atau langgar. Nganggung merupakan rangkaian kegiatan yang mencerminkan nilai-nilai kebersamaan, saling membantu antarwarga dalam suatu desa atau kampung. Walaupun dihadapkan dengan derasnya arus zaman, kegiatan ini masih berlanjut dan diapresiasi masyarakat dalam berbagai kepentingan yang termaktub di dalamnya. Nganggung dilakukan untuk menyambut datangnya hari besar keagamaan, menghormati orang yang meninggal dunia atau menyambut kedatangan tamu besar, seperti Gubernur atau Bupati. Jika di lihat dari perpsfektif islam tradisi nganggung ini identik dengan konsep takaful karena dalam takaful juga ada unsur saling tolong menolong (ta'awun), saling bagi kasih sayang (tarahum) diantara anggota masyarakat muslim. Baik takaful di bidang materi dan moral, ekonomi dan politik, militer dan sipil, serta sosial dan budaya. Takaful dimulai dengan yang mempunyai hubungan kerabat antara sebagian dengan sebagian yang lainnya, sebagaimana hal itu dijelaskan secara rinci dalam aturan nafkah menurut syariat Islam. Maka keluarga yang kaya memberikan infaq kepada keluarga yang miskin sesuai dengan syarat-syarat dan hukum-hukum yang dijelaskan di dalam fiqh Islam. nganggung juga bisa masuk dalam kategorisasi konsep silaturahim. Silaturrahmi tersusun dari dua kosa kata Arab; shilah yang berarti menyambung dan rahim yang berarti rahim wanita, dan dipakai bahasa kiasan untuk makna hubungan kerabat. Jadi silaturrahim bermakna: menyambung hubungan dengan kerabat. Dari keterangan ini, bisa disimpulkan bahwa secara bahasa Arab dan istilah syar'i, penggunaan kata silaturrahim untuk makna sembarang pertemuan atau kunjungan dengan orang-orang yang tidak memiliki hubungan kerabat, sebenarnya kurang pas.

Silaturrahim bukanlah murni adat istiadat, namun ia merupakan bagian dari syariat. Amat bervariasi cara agama kita dalam memotivasi umatnya untuk memperhatikan silaturrahim. Terkadang dengan bentuk perintah secara gamblang, janji ganjaran menarik, atau juga dengan cara ancaman bagi mereka yang tidak menjalankannya.

b. Maulid Nabi

Peringatan Maulid Nabi merupakan kegiatan keagamaan yang sering ditemui diberbagai daerah di Indonesia tidak hanya di Bangka saja. Namun ada hal yang membedakan Antara peringatan maulid Nabi di Bangka dengan daerah lain. Hal yang paling kentara dalam prosesi upacara Maulid Nabi Muhammad SAW di Bangka adalah antusiasme dan partisipasi masyarakat Bangka. Masyarakat Bangka, khususnya di desa Kemuja dan desa Kace Kabupaten Bangka, memperingati Maulid Nabi dengan antusias yang sangat tinggi. Hal ini dapat dilihat dari keramaian yang terjadi sepanjang kegiatan tersebut dilaksanakan. Mereka berbondong-bondong ke masjid dengan membawa makanan atau sekedar mengikuti pengajian kemudian dilanjutkan dengan silaturahmi dengan tetanggatetangga layaknya perayaan hari raya Idul Fitri yang terjadi di pulau Jawa.

Adapun ritual yang dilakukannya yaitu pertama-tama setelah membaca fatihah untuk Rasulullah saw dan yang lainya dilanjutkan dengan membaca riwayat nabi yakni kitab arab melayu yang didalamnya berisikan kisah nabi Muhammad saw mulai dari lahir sampai wafatnya. Setelah selesai membaca haul dilanjutkan dengan membaca tahlil dan do'a. Setelah semua ritual itu dijalankan maka dilanjutkan deengan makan bersama ${ }^{12}$.

Nganggung untuk perayaan maulud dilaksanakan bukan hanya di malam hari. Nganggung dilaksanakan juga di pagi harinya. Semua warga yang berdomisili di Desa Kace dianjurkan untuk nganggung bersama-sama di mesjid yang terdekat dari rumah tinggalnya. Adapun prosesi acara di pagi hari tidak sama lagi seperti di malam harinya. Untuk acara di pagi hari hanya diisi tahlilan saja tidak ada pembacaan riwayat nabi.

${ }^{12}$ Wawancara dengan bapak Basri, MA, beliau adalah salah satu Tokoh Agama Desa Kace dan juga sebagai pengurus Mesjid As-Salam Desa Kace, wawancara pada tanggal 5 Agustus 2016, pukul 20.00 WIB. 
c. Khataman qur'an

Hampir sama dengan perayaan Maulid Nabi Muhammad SAW, khataman Al-quran merupakan salah satu tradisi keagaaman yang dilaksanakan masyarakat Bangka dengan upacara Nganggung. Kegiatan ini merupakan salah satu bentuk aprisiasi masyarakat kepada remaja atau santri yang telah berhasil mempelajari atau membaca Al-quran secara penuh 30 dzus. Acara ini biasanya diadakan sebelum puasa Ramadhan, daerah yang sering melaksanakan kegiatan ini adalah Kelurahan Pintu Air Pangkalpinang. Acara dimulai dengan kegiatan membaca Al-quran yang diwakili oleh beberapa orang santri setelah selesai masyarakat dipersilahkan mendengarkan tausiah keagamaan oleh ulama atau tokoh agama kemudian diakhiri dengan acara nganggung.

\section{H. Konsep Islam Nusantara Menurut Ahmad baso}

Buku ini membicarakan tentang Islam Nusantara dari sisi konstruksi atau racikan ulamaulama Nusantara (Indonesia), dari dalam pesantren,sebagaimana ditulis, didakwahkan oleh para ulama Nusantara, dan diamalkan oleh mayoritas bangsa Indonesia. Pesan khusus yang terdapat dalam buku ini adalah ada banyak hal yang harus kita lakukan untuk meneguhkan kembali Islam Nusantara. Yang paling penting, harus ada semangat di kalangan para kiai, pengurus NU, dan guru-guru di seluruh penjuru Nusantara untuk mewajibkan para santri dan pelajar di pesantren, sekolah, madrasah, kampus, dan di mana pun untuk mengkaji kembali khasanah Islam Nusantara. Gali kembali naskah-naskah kita yang dulu menjadi kiblat umat Islam di dunia. Karya-karya tulisan ulama terdahulu seperti hikayat, serat, atau babat harus digali kembali untuk memperkaya khazanah pemikiran dan kurikulum kita yang kebanyakan kini diisi ilmu-ilmu impor dari luar. Padahal ilmu-ilmunya ulama kita banyak berisi ensiklopedi pemikiran jenius ulama Islam Nusantara. Bukan hanya jago membahas masalah-masalah agama, para ulama kita jago dalam meracik ilmu politik hingga ilmu ekonomi, yang bahkan di Arab maupun di Barat tidak dikenal sama sekali.

Awal kemunculan buku ini sempat mengundang kontroversi. Setelah judul buku ini menjadi tema besar Muktamar NU tahun 2015 di Jombang, istilah Islam Nusantara banyak dibicarakan oleh sebagian masyarakat Indonesia sebagai upaya memudarkan ajaran Islam itu sendiri. Mereka berpendapat bahwa tidak ada istilah Islam Nusantara karena Islam adalah Islam, tidak mengenal Islam yang bersifat ke-daerahan, kesukuan, atau mewakili suatu Negara. Islam turun ke dunia untuk seluruh umat manusia, Islam itu rahmatan lil alamin. Islam itu dibangun di atas landasan yang satu, yaitu Alquran dan Sunnah.

Islam Nusantara yang menjadi tema utama muktamar NU ke-33 di Jombang pada 2015, menuai pro kontra. Dari pandangan NU, konsepsi "Islam Nusantara" mengacu pada fakta sejarah betapa dakwah Islam di nusantara tidak dilakukan dengan pemberangusan terhadap budaya setempat, melainkan justru dengan merangkul dan menyelaraskannya dengan Islam. NU bertekad mempertahankan Islam Nusantara yang berciri toleran, moderat dan damai. Namun dari pandangan yang kontra, "Islam Nusantara" dianggap sebagai bermuatan primordial, anti Arab, bahkan dituduh sebagai strategi baru dari JIL, Barat, Zionis, dan semacamnya.

Dengan latar belakang kontroversi semacam itu, upaya untuk membedah wacana Islam Nusantara dari perspektif doktrinal maupun historis menjadi sangat diperlukan. Bagaimana Islam Nusantara dilihat dari sudut pandang fikih dan ushûl fiqh? Bagaimana pula dari sudut pandang Aswaja dan tasawuf? Seperti apakah relasi antara universalitas Islam, budaya lokal, dan budaya Arab? Seberapa jauh wacana Islam Nusantara bisa dibandingkan dengan wacana sejenis sebelumnya, seperti "fikih Indonesia" ala Prof. Hasbi As-Shiddiqi, "pribumisasi Islam" ala Gus Dur, dan "fikih sosial" KH. Sahal Mahfudh? Inilah sebagian dari pertanyaan yang menjadi agenda pembahasan buku ini.

Buku ini menjelaskan bahwa maksud dari istilah Islam Nusantara adalah Islam yang selain dibangun di atas landasan Alquran dan Sunnah, Islam memiliki acuan maqashid syaria'ah 
(tujian syariat). Tujuan syariat ini dapat digali dari nash-nash syariah melalui sekian istiqro' (penelitian induktif). Ulama-ulama terdahulu menjelaskan bahwa di balik aturan-aturan syariat ada tujuan yang hendak dicapai, yaitu terwujudnya kemaslahatan manusia di dunia dan akhirat. Kemaslahatan semakna dengan kebaikan dan kemanfataan. Tujuan Negara dalam Islam sejatinya sejalan dengan tujuan syariat, yaitu terwujudnya keadilan dan kemakmuran yang berKetuhanan yang Maha Esa. Oleh karena itu, istilah Islam Nusantara sejati menggambarkan bahwa tujuan Islam sejalan dengan terbentuknya Nusantara (Indonesia).

Oleh karenanya, prinsip-prinsip menjalankan ajaran Islam sepenuhnya harus selalu berpegang teguh dengan Alquran dan Sunnah. Selain itu, prinsip-prinsip tersebut juga dapat disesuaikan dengan dalil-dalil sekunder (selain Alquran dan Sunnah) sepanjang prinsip-prinsip tersebut tidak memiliki acuan nash secara langsung. Dalil-dalil sekunder yang dimaksud seperti Ijma, al-Qiyas, Istihsan, Saddu-dz-dzariah, 'urf, dan lain-lainnya. Hal tersebut juga menjelaskan bahwa hukum itu tidak selalu tekstual tetapi juga kontekstual sepanjang tujuannya adalah kemaslahatan. Istilah Islam Nusantara hanya sebagai lambang bahwa faham dan praktik keislaman di bumi Nusantara adalah sebagai hasil dialektika antara teks syariat dengan realita dan budaya setempat.

Bagian pertama buku Islam Nusantara ini disajikan dengan model dialog antara seorang Kiai Afid dan santrinya. Tujuan penulisnya, Ahmad Baso, agar mudah dipahami oleh pembaca tentang apa pesan yang ingin disampaikannya. Tentang mengapa harus ada Islam Nusantara, bagaimana ia lahir, tentang silsilah dan sanadnya, dan metodologi Islam Nusantara.Ahmad Baso mendefinisikan Islam Nusantara dengan "cara bermazhab secara qauli dan manhaji dalam beristinbath tentang Islam dari dalil-dalilnya yang disesuaikan dengan teritori, wilayah, kondisi alam, dan cara penduduk mengamalkan."

Nahdlatul Ulama (NU) sejak dulu telah merepresentasikan Islam rahmatan lil 'alamin melalui kegiatan-kegiatan keagamaan yang mulanya berasal dari budaya setempat. Islam Nusantara, sebagaimana diterangkan dalam buku Islam Nusantara ini, bukanlah subyek yang pasif, yang asal menerima apa saja yang datang dari Arab. Melalui kegiatan tahlil, shalawatan, halal bi halal, dan sebagainya, Islam Nusatara membuktikan bahwa Islam bisa dikemas dengan cara yang buka Arab.

Islam terlahir di Arab, kemudian menyebar ke seluruh dunia, tanpa terkecuali Indonesia. Setelah para penyebar Islam datang di Indonesia, mereka menyebarkannya dengan jalan perdamaian. Melalui jalan perdagangan, perkawinan, dan bukan dengan paksaan. Tidak seperti penyebaran Islam di daerah Eropa melalui penaklukan dan peperangan. Di masa Wali Songo pula, Islam tersebar dengan cara damai. Untuk menarik hati umat, Wali Songo lebih menampilkan sikap yang lemah lembut. Wali Songo selalu memanfaatkan budaya lokal sebagai sarana dakwah. Misalnya Sunan Kudus yang dengan arsitektur Menara Kudus dan pelarangan menyembelih sapi bisa membuat masyarakat Hindu bersimpati. Setelah mendapat perhatian dari orang-orang yang belum Islam, di situlah Wali Songo mudah dalam menjalankan dakwahnya.

Sunan Kalijaga sangat toleran terhadap budaya local. Ia berkeyakinan bahwa masyarakat akan menjauh jika pendirian mereka diserang. Maka mereka harus didekati secara bertahap, mengikuti sambil mempengaruhi. Ia juga berkeyakinan bahwa jika Islam sudah dipahami, dengan sendirinya kebiasaan lama akan hilang. Maka ajaran Sunan Kalijaga terkesan sinkretis dalam mengenalkan ajaran Islam. Ia menggunkana seni ukir, wayang, gamelan, serta seni suara suluk sebagai sarana dakwah. Metode dakwah tersebut kreatif dan juga sangat efektif. Sejarah membuktikan bahwa sebagaian besar adipati di Jawa memeluk agama Islam melalui Sunan Kalijaga. Demikian juga dengan metode yang digunakan oleh Sunan Kudus. Ia mendekati masyarakat melalui simbol-simbol Hindu-Budha. Hal tersebut dapat terlihat dari bentuk arsitektur Masjid Kudus. Menara, gerbang, dan pancuran/padasan wudhu yang melambangkan delapan jalan Budha. Sebuah wujud kompromi yang dilakukan oleh Sunan Kudus. Dalam kondisi sekarang, Islam tentu menghadapi masalah yang amat pelik. Di 
antaranya kisruh kekerasan dan jalan dakwah yang radikal. Kelompok-kelompok garis keras masih berkeliaran di muka bumi, terutama di Timur Tengah dengan nama -yang paling terkenal- ISIS. Cara dakwah yang sama sekali bertentangan dengan metode dakwah yang dipakai oleh Wali Songo ini justeru merusak citra Islam sendiri.

Kemunculan kelompok Islam radikal di Indonesia mengganggu berjalannya Islam Nusantara yang dipegang teguh oleh umat muslim Indonesia. Banyak ijtihad ulama Islam Nusantara yang ternyata tidak ditemukan dalam kitab-kitab ulama klasik (salaf), apalagi dalam al-Qur'an dan Hadits. Bukan berarti ijthad ulama Nusantara meninggalkan dua asas Islam tersebut, bahkan bertentangan. Yang diambil oleh ulama Islam Nusantara adalah spirit Islam, bukan bentuk luar Islam itu sendiri. Maka, selama bentuk sebuah ibadah sulit diterapkan, budaya lokal yang akan mewadahinya.

Prinsip yang dipegang Islam Nusantara adalah prinsip al-muhafadhoh alal qadimis shalih wal akhdzu bil jadid al ashlah, menjaga kesalehan yang dahulu dan mengambil hal baru yang lebih baik. Oleh karena itu, Islam Nusantara tidak menjadi kaku dan tetap mempunya ciri khas. Islam Nusantara tercermin dalam kehidupan di pondok pesantren, sebagai markas sesungguhnya Nahdlatul Ulama. Jadi sudah seharusnya Islam menjadi air yang ketika ia menempati Nusantara, ia akan berbentuk sesuai wadahnya. Islam tidak boleh dipaksakan harus sesuai dengan apa yang dilakukan oleh orang-orang zaman dahulu, pada masa Rasul atau setelahnya. Karena Islam itu salih li kulli zaman wa makan, patut di segala waktu dan tempat.

Buku ini menjadi penting karena menjelaskan bahwa Islam Indonesia mempunyai sejarahnnya sendiri. Sejarah yang sama sekali berbeda dengan sejarah Islam di Arab dan negara-negara lain. Dengan melihat apa yang terjadi pada masa Wali Songo, sebelumnya, bahkan setelahnya, kita akan memahami proses meluasnya Islam di Indonesia sehingga menjadi negara dengan penduduk Islam terbesar di dunia.

Terma 'Islam Nusantara' menjadi perbincangan masyarakat Indonesia tidak lama setelah Pengurus Besar Nahdlatul Ulama (PBNU) menetapkannya sebagai tema Muktamar NU Ke-33 di Jombang pada tanggal 1-5 Agustus 2015, "Meneguhkan Islam Nusantara untuk Peradaban Indonesia dan Dunia". Berbagai diskusi digelar, begitu juga puluhan artikel muncul di media nasional, dari tulisan mahasiswa hingga Guru Besar. Tak pernah terjadi dalam sejarah NU sebelumnya tema Muktamar bisa meledak dan jadi bahan diskusi seramai ini. Di antara pemikiran yang muncul tentang 'Islam Nusantara' adalah mengkomparasikannya dengan istilah 'Islam: The Straight Path' yang diterjemahkan ke dalam bahasa Indonesia, 'Islam: Jalan Lurus', atau Islam: Shiratal Mustaqim. Memaknai 'Islam: The Straight Path' dengan 'Islam: Jalan Lurus' memang tidak menimbulkan pergeseran pemahaman. Namun menjadi persoalan besar jika menyamakan makna 'Islam: The Straight Path' (Islam: Jalan Lurus) dengan 'Islam: Sirathal Mustaqim'.

\section{KESIMPULAN}

Dari sisi substansi, terma 'Islam Nusantara' itu paham dan praktik keislaman di bumi Nusantara sebagai hasil dialektika antara teks syariat dengan realita dan budaya setempat. Spirit 'Islam Nusantara' adalah praktik berislam yang didahului dialektika antara nash syariah dengan realitas dan budaya tempat umat Islam tinggal. Perspektif ushul fiqh, proses dialektika antara nash syariah dengan realitas dan budaya tempat umat Islam tinggal itu sesuatu yang lumrah terjadi bahkan pasti terjadi mengingat Islam itu ajaran yang universal. Dan 'Islam Nusantara' adalah wujud Islam sebagai agama universal mengingat ia telah dipeluk oleh ratusan juta penduduk Nusantara dan telah melahirkan ratusan ribu produk hukum dan khazanah keislaman lainnya. Bertolak dari pemahaman di atas, tak perlu takut Islam terdistorsi gara-gara muncul terma 'Islam Nusantara', atau bahkan nanti menyusul muncul terma 'Islam Amerika', 'Islam Eropa', 'Islam Australia', 'Islam Afrika, dan lainnya.

Masyarakat Islam tradisional di pulau Bangka pada musim atau hari tertentu tertentu 
melakukan ritual nganggung. Nganggung adalah bentuk konversi kepercayaan non Islam ke agama Islam. Nganggung bukan merupakan wujud konversi melainkan wujud dari hasil dialektika antara nash syariah dengan budaya setempat. Artinya, Nganggung yang masih bertahan di tengah masyarakat Bangka tidak pertentangan dengan Islam. Jika proses Nganggung itu sebatas konversi tentu tak ada gunanya Islam mereka anut. Budaya yang telah mendapatkan legitimasi nash syariah menjelma menjadi ritual ibadah. Proses ini merupakan sesuatu yang lumrah terjadi di lingkungan para kiai di Nusantara. Sehingga keislaman masyarakat Nusantara mempunyai corak yang sama karena referensi (masyrab wal ma'khadz) dan konsep pemikirannya yang tunggal (ittifaqul ara').

Bagi kelompok tertentu, terma 'Islam Nusantara' itu diyakini gagasan yang tidak masuk akal sehingga patut diremehkan. 'Islam Nusantara' dianggap sebagai sisi gelap agama Islam. Belajar dari logika Antoni Giddens, padahal jika ingin benar-benar memahami tradisi perlu tidak menganggap 'Islam Nusantara' sebagai ketololan. Para intelektual muslim perlu mendekati gagasan 'Islam Nusantara' secara hati-hati. Terma 'Islam Nusantara' juga bagian dari ide kreatif para kiai sebagai bagian dari ekspresi kesetiaan terhadap ilmu keislaman yang bercirikan tradisional.

\section{DAFTAR PUSTAKA}

Azra, Azyumardi. 2015. Jaringan Ulama Timur Tengah dan Kepulauan Nusantara Abad XVII dan XVIII, Akar Pembaruan Islam Indonesia, Edisi Revisi, Cet. 1, Jakarta: Kencana

Baso, Ahmad. 2015. Islam Nusantara: Ijtihad Jenius \& Ijma’ Ulama Nusantara, Jilid I. Jakarta: Pustaka Afid Jakarta.

Purwadarminta, W.J.S. 1991. Kamus Umum Bahasa Indonesia. Jakarta: Balai Pustaka

Zulkifli. 2007. Kontuinitas Islam Tradisional di Bangka. Bangka: Shiddiq Press.

KH Afifuddin Muhajir. http://www.nu.or.id/post/read/60458/maksud-istilah-islam-nusantara. Diakses pada tanggal 5 Maret 2016. 